\title{
Effect of Sowing Dates and Weed Control Measure on Growth and Yield of Chickpea in Western Rajasthan
}

\author{
Mahaveer $^{1}$, M. L. Reager $^{2}$ and Shri Rakesh ${ }^{1 *}$ \\ ${ }^{1}$ Department of Agronomy, Collage of Agriculture, ${ }^{2}$ Krishi Vigyan Kendra, Swami \\ Keshwanand Rajasthan Agricultural University, Bikaner, Rajasthan - 334006, India
}

*Corresponding author

\section{A B S T R A C T}

\begin{tabular}{|l|}
\hline K e y w o r d s \\
Crop growth rate, \\
Relative growth \\
rate, Pendimethalin, \\
Quizalofop
\end{tabular}

An experiment was carried out during rabi 2015-16 to evaluate growth and yield of chickpea under different sowing dates and weed control measure. The experiment was laid out in split-plot design with three replications, assigning twenty treatments consisting of four date of sowing (15 October, 30 October, 15 November and 30 November) as main plot treatments and five weed control measure (Weedy check, Weed free, Pendimethalin @ $0.75 \mathrm{~kg} / \mathrm{ha}$ as pre emergence, Imazethapyr @ $20 \mathrm{~g} / \mathrm{ha}$ at 20 DAS as post emergence and Quizalofop@ $37.5 \mathrm{~g} / \mathrm{ha}$ at 20 DAS as post emergence) as sub-plots. Sowing of crop on 15 October remained statistically at par with sowing on 30 October recorded significantly higher growth parameters viz. plant height, dry matter accumulation, relative growth rate and yield attributing characters viz. number of branches/plant, number of pods/plant, number of seeds/pod, test weight, seed yield, straw yield, biological yield, harvest index, net return and B:C ratio as compared to 15 November and 30 November. In case of weed control measures, weed free recorded higher growth attributing characters viz. plant height, dry matter accumulation, relative growth rate and yield attributing characters viz. number of branches/plant, number of pods/plant, number of seeds/pod, seed yield, straw yield, biological yield, net return and B:C ratio followed by Pendimethalin@0.75 kg/ha as PE and Quizalofop @ $37.5 \mathrm{~g} / \mathrm{ha}$ as PoE.

\section{Introduction}

Chickpea (Cicer arietinum L.) a legume is popularly known as "Gram" or "Bengal gram" play an important role in Indian economy. It belongs to family Leguminoseae being a rich and cheap source of protein, can help people to improve the nutritional quality of their diet. India is the largest acreage holder and producer of chick pea in the world. In India, it covers 10.56 million hectares cultivated area and 11.23 million tonnes an annual production with productivity of 1063 $\mathrm{kg} / \mathrm{ha}$ in 2017-18 (GOI, 2018).

In Rajasthan, it is covers 15.97 lakh hectares area and produced 18.67 lakh tonnes with the productivity $1169 \mathrm{~kg} / \mathrm{ha}$ in 2018-19 (GOR 2019). In general, the chickpea is cultivated on marginal and sub marginal lands under rainfed conditions as early sown. This early sown crop results in excessive vegetative 
growth, poor setting of pods and greater weed competition, whereas in double cropping areas due to cultivation of long duration in kharif crop varieties, the planting of chickpea is usually delayed. Under such situation, the crop has to be sown up to December only. This late sown crop experiences very low temperature at initial stages of crop growth resulting in poor and slow vegetative growth, whereas the early sown crop allows better yield and growth improvement (Mohammadnejad and Soltani, 2005).

Weeds are one of the important factor responsible for low productivity of chick pea reduced 30-54 per cent (Mukherjee, 2007) which is responsible for reducing crop growth by two mechanism, i.e. completion for resources and allelopathic effect. In the initial growth of crop there is relatively shallow canopy and it slowly shades the inter-row area, which allows bumper weeds growth and thus chick pea becomes more susceptible to weed crop competition. Herbicides are most effective and economic weed control measures but always use of herbicides is not feasible due to some unavoidable circumstances like unavailability of proper herbicides, cropping system requirement and problem of weed flora shift due to continuous use of same group of herbicides. Thus, it is necessity to explore and test other alternative and economical methods of weed control. The high cost and non-availability of labour at right time force the farmers for opting alternative, cheaper and easier method of weed control. Several herbicides viz. pendimethalin, quizalofop and imazethapyr are presently being used for controlling both grassy and broad-leaved weeds but their effects under different climatic conditions are not well defined. A good weed management practice with sowing at right time may help in realizing better yield. Early or delayed sowing reduces the optimum plant population which plays an important role in improving the productivity of crop (Kumar et al., 2003). With this view field experiments were conducted to identify the optimum sowing time, and appropriate weed control measure for the growth and yield performance in chickpea.

\section{Materials and Methods}

The field experiment was conducted during rabi season of 2015-16 at Instructional Farm, College of Agriculture, Swami Keshwanand Rajasthan Agricultural University, Bikaner, Rajasthan, India, which is situated at a $28^{\circ}$ $01^{\prime} \mathrm{N}$ latitude and $73^{\circ} 22^{\prime} \mathrm{E}$ longitude at an altitude of 234.70 meters above mean sea level). The soil of experimental field was loamy-sand, alkaline in reaction $(\mathrm{pH}$ 8.38) having $89.25 \mathrm{~kg} / \mathrm{ha}$ available $\mathrm{N}$, low in available phosphorus (19.5 $\mathrm{kg} \mathrm{ha}^{-1}$,) and medium in available potassium (190.35 $\mathrm{kg} / \mathrm{ha}$ ) in $0-15 \mathrm{~cm}$ soil depth at the start of the experiment. The experiment was laid out in split-plot design with three replications, assigning twenty treatments consisting of four date of sowing (15 October, 30 October, 15 November and 30 November) as main plot treatments and five weed control measure (Weedy check, Weed free, Pendimethalin@ $0.75 \mathrm{~kg} / \mathrm{ha}$ as pre emergence, Imazethapyr @ $20 \mathrm{~g} / \mathrm{ha}$ at 20 DAS as post emergence and Quizalofop@ $37.5 \mathrm{~g} / \mathrm{ha}$ at $20 \mathrm{DAS}$ as post emergence) as sub-plots.

The sowing of chick pea variety GNG-1581 using seed rate of $60 \mathrm{~kg} / \mathrm{ha}$ and maintained crop geometry $30 \times 10 \mathrm{~cm}$ was done on scheduled dates of sowing. The rainfall received during growing period (October to April) was $31.3 \mathrm{~mm}$ in 04 rainy days. The mean weekly minimum and maximum temperature during the crop season fluctuated from 4.0 to $37.3^{\circ} \mathrm{c}$ with the average relative humidity from 51.4 to $91.8 \%$. Experimental crop was raised as per recommended package of practices. 
The data obtained were statistically analyzed accord with the Split Plot Design. Analysis of variance was used to test the significance of treatment effects at 5 percent level of probability. Least Significant Difference (LSD) Test was used to compare treatment means.

\section{Results and Discussion}

\section{Effect of date of sowing}

The results revealed that different sowing dates influences growth parameters like plant height, periodical dry matter production, crop growth rate, and relative growth rate, yields attributing character viz. branches/plant, pods/plant, seeds/pod, test weight, seed, straw, biological yield and harvest index (Table 1 and 2). Sowing date treatments did not influenced the plant height of chickpea at 30 DAS. However, at harvest, plant height of chickpea remained statistically at par from 15 October to 30 October. Further delaying the sowing up to 30 November significantly decreased the plant height of chickpea. Prasad (2009) also reported that reduction in plant height with the delay in sowing time. Dry matter production of chickpea at 30 and 60 DAS increased significantly, with delaying date of sowing up to 30 October. However, dry matter production of chickpea at 90 DAS and at harvest, 15 October remained statistically at par with 30 October, significantly decreased with further delayed sowing dates up to 30 November. Kumar et al., (2006) also reported that reduction in dry matter accumulation and other physiological parameters with the delay in sowing beyond October.

Crop growth rate of chickpea were increased with delaying sowing up to 30 November (except crop growth rate between 60-90 DAS). Sowing of the crop on 30 November remained statistically at par with crop sown on 15 November, recorded the highest crop growth rate of $0.019,0.129$ and 0.201 $\mathrm{g} / \mathrm{m}^{2} /$ day between $0-30,30-60$ and 90 DAS to harvest, respectively, over crop sown on 15 October and 30 October. Relative growth rate of chickpea between 30 and 60 DAS increased significantly, with delaying sowing; however, it was decreased with delaying sowing between 60 to 90 DAS and 90 DAS to harvest. Sowing of the crop on 30 November recorded the highest relative growth rate of $0.65 \mathrm{mg} / \mathrm{g}^{\prime}$ day between 30 to 60 DAS which was statistically at par with crop sown on 15 November and 30 October, compared to crop sown on 15 October. However, sowing of the crop on 15 October, was statistically at par with crop sown on 30 October, recorded the highest relative growth rate of 0.93 and 1.21 $\mathrm{mg} / \mathrm{g}$ 'day between 60-90 DAS and 90 DAS to harvest, respectively, compared to crop sown on 15 November and 30 November.

Highest number of branches/plant, pods/plant, seeds/pod, test weight, seed, straw, biological yield was recorded by crop sown on 15 October which was statistically at par with 30 October over sowing on 15 November and 30 November. The percentage increases in number of branches/plant (18.49 \& 38.12), number of seeds/pod (16.43 \& 41.74), as compared to crop sown on 15 November and 30 November, respectively. Sowing on 15 October increased pods/plant of chickpea by 12.57, 30.00 and 69.82 per cent over chickpea sown on 30 October, 15 November and 30 November, respectively. This is completely agreed with the findings of Rajput et al., (1986) who observed higher values of pods/plant with the early sowing. Sowing on 15 October increased test weight to the tune of 10.60 per cent over sown on 30 November. The percentage increases in seed yield (17.69, $\&$ 43.20), straw yield (12.05 \& 36.29) and biological yield (13.99 \& 38.67) as compared to crop sown on 15 November and 30 November, respectively. 
The reduction in seed yield under delayed sowings due to shortening of life span coupled with lesser biomass production in chickpea crop had also been reported by Ray et al., (2011). The sowing on 15 October enhanced the harvest index of chickpea by $3.25,3.31$ and 3.52 per cent, respectively, over delay crop sown on 30 October, 15 November and 30 November.

The comparative economics of chick pea is presented in Table 2. Data of the present investigation revealed that to raise an economical crop of Chickpea, optimum sowing time and proper weed management is must. Crop sown on 15 October recorded highest net return (89368 ₹/ha) and B:C ratio (5.24). Higher harvest index in case of early sowing might be due to more economic yield rather than total biomass production. The findings confirmed the results of Prasad et al., (2012).

\section{Effect of weed control measures}

Effect of different weed control measures was also observed on growth parameters like plant height, periodical dry matter production, crop growth rate, and relative growth rate, yields attributing character viz. branches/plant, pods/plant, seeds/pod, test weight, seed, straw and biological yield (Table 1 and 2). Significantly lower values of these parameters were recorded under weedy check and highest values of these were recorded in weed free plot.

Among chemical weed control treatments highest plant height was observed by application of pendimethalin @ $0.75 \mathrm{~kg} / \mathrm{ha}$ as PE, followed by quizalofop @ $37.5 \mathrm{~g} / \mathrm{ha}$. Arya (2004) also reported higher plant height in herbicidal treated plots. Application of weed control measures as pendimethalin @ $0.75 \mathrm{~kg} / \mathrm{ha}$ PE, quizalofop @ $37.5 \mathrm{~g} / \mathrm{ha}$ as PoE and imazethapyr $20 \mathrm{~g} / \mathrm{ha}$ as PoE, respectively, increased plant height of chickpea by 29.42 , 20.30 and 10.38 per cent as compared to weedy check. Imazethapyr have detrimental effect on plant height $(41.38 \mathrm{~cm})$ of chickpea which was next lowest. Application of weed control measures as pendimethalin @ 0.75 kg/ha, quizalofop @ 37.5 g/ha and imazethapyr @ 20 g/ha, respectively, increased dry matter production of chickpea by $33.95,31.79$ and 25.93 per cent at 60 DAS, $35.47,33.07$ and 26.97 per cent at 90 DAS and 29.38, 21.67 and 12.26 per cent at harvest as compared to weedy check.

Highest crop growth rate $0.142,0.152$ and $0.203 \mathrm{~g} / \mathrm{m}^{2} /$ day were found in weed free treatment, further $0.126,0.136$ and 0.166 $\mathrm{g} / \mathrm{m}^{2} /$ day were recorded in pendimethalin@ $0.75 \mathrm{~kg} / \mathrm{ha}$, respectively at 60, $90 \mathrm{DAS}$ and at harvest of chickpea. At 30 DAS crop growth rate in weedy check remained statistically at par with weed free and pendimethalin @ 0.75 $\mathrm{kg} / \mathrm{ha}$. Highest relative growth rate $0.69,0.95$ and $1.25 \mathrm{mg} / \mathrm{g} /$ day were recorded in weed free treatment, further $0.64,0.89$ and 1.18 $\mathrm{mg} / \mathrm{g} /$ day were recorded in pendimethalin@ $0.75 \mathrm{~kg} / \mathrm{ha}$, respectively, between 30-60, 6090 DAS and 90 DAS to harvest of chickpea.

Significantly higher number of branches/plant, number of pod/plant and number of seeds/pod was counted under weed free treatment as compared to all chemical weed control measures. Both pendimethalin @ $0.75 \mathrm{~kg} / \mathrm{ha}$ and quizalofop @ $37.5 \mathrm{~g} / \mathrm{ha}$ were at par with each other, produced significantly higher number of branches/plant, number of pod/plant and number of seeds/pod as compared to weedy check and imazethapyr @ $20 \mathrm{~g} / \mathrm{ha}$ (Table 2). Application of pendimethalin@0.75 kg/ha and quizalofop @ $37.5 \mathrm{~g} / \mathrm{ha}$, respectively, increased number of branches/plant (51.25\& 48.09 per cent), number of pods/plant (21.29 \& 17.30 per cent) and number of seeds/pod (24.59 \& 23.77 per cent) as compared to weedy check. 
Table.1 Effect of sowing date and weed control measures on growth parameters of chick pea

\begin{tabular}{|c|c|c|c|c|c|c|c|c|c|c|c|c|c|}
\hline \multirow[t]{2}{*}{ Treatments } & \multicolumn{2}{|c|}{$\begin{array}{l}\text { Plant height } \\
\quad(\mathrm{cm})\end{array}$} & \multicolumn{4}{|c|}{ Dry matter accumulation (g/plant) } & \multicolumn{4}{|c|}{ CGR $\left(g / m^{2} /\right.$ day $)$} & \multicolumn{3}{|c|}{ RGR (mg/g/day) } \\
\hline & $\begin{array}{c}\text { 30 } \\
\text { DAS }\end{array}$ & $\begin{array}{c}\text { At } \\
\text { harvest }\end{array}$ & 30 DAS & 60 DAS & 90 DAS & $\begin{array}{c}\text { At } \\
\text { harvest }\end{array}$ & $\begin{array}{l}0-30 \\
\text { DAS }\end{array}$ & $\begin{array}{l}\text { 30-60 } \\
\text { DAS }\end{array}$ & $\begin{array}{l}\text { 60-90 } \\
\text { DAS }\end{array}$ & $\begin{array}{l}90 \text { DAS- } \\
\text { Harvest }\end{array}$ & $\begin{array}{l}30-60 \\
\text { DAS }\end{array}$ & $\begin{array}{l}\text { 60-90 } \\
\text { DAS }\end{array}$ & $\begin{array}{l}90 \text { DAS- } \\
\text { Harvest }\end{array}$ \\
\hline \multicolumn{14}{|l|}{ Sowing dates } \\
\hline 15 October & 8.78 & 49.00 & 0.48 & 3.48 & 8.87 & 16.71 & 0.016 & 0.100 & 0.180 & 0.121 & 0.51 & 0.93 & 1.21 \\
\hline 30 October & 8.73 & 47.91 & 0.53 & 4.31 & 8.77 & 16.16 & 0.018 & 0.126 & 0.149 & 0.148 & 0.64 & 0.92 & 1.18 \\
\hline 15 November & 8.61 & 44.03 & 0.56 & 4.39 & 7.62 & 14.65 & 0.019 & 0.127 & 0.108 & 0.156 & 0.65 & 0.86 & 1.15 \\
\hline 30 November & 8.18 & 39.01 & 0.57 & 4.43 & 6.96 & 12.98 & 0.019 & 0.129 & 0.084 & 0.201 & 0.65 & 0.78 & 1.09 \\
\hline SEm \pm & 0.26 & 1.05 & 0.01 & 0.13 & 0.25 & 0.26 & 0.0004 & 0.004 & 0.011 & 0.000 & 0.01 & 0.01 & 0.01 \\
\hline $\mathrm{CD}(\mathrm{P}=0.05)$ & NS & 3.65 & 0.04 & 0.44 & 0.87 & 0.89 & 0.001 & 0.015 & 0.037 & 0.001 & 0.05 & 0.05 & 0.02 \\
\hline \multicolumn{14}{|l|}{ Weed control measures } \\
\hline Weedy check & 8.68 & 37.49 & 0.55 & 3.24 & 6.23 & 12.32 & 0.018 & 0.090 & 0.100 & 0.143 & 0.48 & 0.74 & 1.07 \\
\hline Weed free & 8.71 & 52.44 & 0.55 & 4.82 & 9.40 & 18.55 & 0.018 & 0.142 & 0.152 & 0.203 & 0.69 & 0.95 & 1.25 \\
\hline $\begin{array}{l}\text { Pendimethalin @ } 0.75 \\
\text { kg ha-1 as PE }\end{array}$ & 8.70 & 48.52 & 0.57 & 4.34 & 8.44 & 15.94 & 0.019 & 0.126 & 0.136 & 0.166 & 0.64 & 0.89 & 1.18 \\
\hline $\begin{array}{l}\text { Imazethapyr @ } 20 \mathrm{~g} \\
\text { ha-1 at } 20 \text { DAS as PoE }\end{array}$ & 8.09 & 41.38 & 0.50 & 4.08 & 7.91 & 13.83 & 0.017 & 0.120 & 0.128 & 0.127 & 0.62 & 0.88 & 1.12 \\
\hline $\begin{array}{l}\text { Quizalofop@ } 37.5 \mathrm{~g} \\
\text { ha-1 at } 20 \text { DAS as PoE }\end{array}$ & 8.70 & 45.10 & 0.52 & 4.27 & 8.29 & 14.99 & 0.017 & 0.125 & 0.134 & 0.144 & 0.64 & 0.90 & 1.15 \\
\hline SEm \pm & 0.23 & 1.03 & 0.01 & 0.13 & 0.26 & 0.26 & 0.0004 & 0.004 & 0.010 & 0.014 & 0.01 & 0.01 & 0.01 \\
\hline $\mathrm{CD}(\mathrm{P}=0.05)$ & NS & 2.98 & 0.04 & 0.37 & 0.75 & 0.75 & 0.001 & 0.012 & 0.028 & 0.039 & 0.04 & 0.04 & 0.02 \\
\hline
\end{tabular}

DAS $=$ Days after sowing, NS $=$ Non-Significant 
Table.2 Effect of sowing dates and weed control measures on yield attributes, yield, harvest index and economics of chick pea

\begin{tabular}{|c|c|c|c|c|c|c|c|c|c|c|}
\hline \multirow[t]{2}{*}{ Treatments } & \multicolumn{4}{|c|}{ Yield attributes } & \multicolumn{3}{|c|}{ Yield (kg/ha) } & \multirow{2}{*}{$\begin{array}{l}\text { Harvest } \\
\text { index } \\
(\%)\end{array}$} & \multicolumn{2}{|c|}{ Economics } \\
\hline & $\begin{array}{l}\text { Branches/ } \\
\text { plant }\end{array}$ & $\begin{array}{l}\text { Pods/ } \\
\text { plant }\end{array}$ & $\begin{array}{c}\text { Seeds/ } \\
\text { pod }\end{array}$ & $\begin{array}{c}\text { Test } \\
\text { weight } \\
\text { (g) }\end{array}$ & Seed & Straw & $\begin{array}{l}\text { Bio } \\
\text { logical }\end{array}$ & & $\begin{array}{c}\text { Net } \\
\text { returns } \\
(₹ / h a)\end{array}$ & $\begin{array}{l}\mathrm{B}: \mathrm{C} \\
\text { ratio }\end{array}$ \\
\hline \multicolumn{11}{|l|}{ Sowing dates } \\
\hline 15 October & 6.92 & 30.72 & 1.63 & 144.4 & 1734.9 & 3142.0 & 4877.0 & 35.60 & 89368 & 5.24 \\
\hline 30 October & 6.42 & 27.29 & 1.57 & 143.1 & 1625.6 & 3089.4 & 4715.0 & 34.48 & 82683 & 4.88 \\
\hline 15 November & 5.84 & 23.63 & 1.40 & 139.4 & 1474.1 & 2804.1 & 4278.3 & 34.46 & 73026 & 4.43 \\
\hline 30 November & 5.01 & 18.09 & 1.15 & 130.6 & 1211.6 & 2305.3 & 3516.9 & 34.39 & 56275 & 3.62 \\
\hline SEm \pm & 0.16 & 0.98 & 0.05 & 2.24 & 42.4 & 80.1 & 122.5 & 0.07 & 2706 & - \\
\hline $\mathrm{CD}(\mathrm{P}=0.05)$ & 0.54 & 3.38 & 0.16 & 7.76 & 146.7 & 277.1 & 423.9 & 0.23 & 9366 & - \\
\hline \multicolumn{11}{|l|}{ Varieties } \\
\hline Weedy check & 5.26 & 18.07 & 1.22 & 136.4 & 1055.7 & 1968.9 & 3024.6 & 34.78 & 48369 & 3.55 \\
\hline Weed free & 7.06 & 31.48 & 1.70 & 143.0 & 1945.2 & 3654.4 & 5599.7 & 34.73 & 99419 & 5.04 \\
\hline $\begin{array}{l}\text { Pendimethalin @ } \\
0.75 \mathrm{~kg} \mathrm{ha}^{-1} \text { as PE }\end{array}$ & 6.38 & 27.33 & 1.52 & 137.7 & 1628.9 & 3061.3 & 4690.2 & 34.72 & 82964 & 4.97 \\
\hline $\begin{array}{l}\text { Imazethapyr @ } 20 \\
\text { g ha }^{-1} \text { at } 20 \text { DAS as } \\
\text { PoE }\end{array}$ & 5.36 & 21.03 & 1.25 & 140.2 & 1328.7 & 2482.7 & 3811.5 & 34.82 & 64639 & 4.22 \\
\hline $\begin{array}{l}\text { Quizalofop@ } 37.5 \mathrm{~g} \\
\text { ha }^{-1} \text { at } 20 \text { DAS as } \\
\text { PoE }\end{array}$ & 6.17 & 26.76 & 1.51 & 139.73 & 1599.1 & 3008.7 & 4607.9 & 34.60 & 81300 & 4.93 \\
\hline SEm \pm & 0.16 & 0.91 & 0.05 & 2.61 & 42.9 & 81.6 & 124.6 & 0.07 & 2740 & - \\
\hline $\mathrm{CD}(\mathrm{P}=0.05)$ & 0.47 & 2.62 & 0.14 & $\mathrm{NS}$ & 123.7 & 235.1 & 358.9 & NS & 7892 & - \\
\hline
\end{tabular}


Weed free treatment produced significantly higher seed, straw and biological yield over rest of all chemical weed control treatments and weedy check. Chemical weed control treatments such as quizalofop @ $37.5 \mathrm{~g} / \mathrm{ha}$ and pendimethalin @ $0.75 \mathrm{~kg} / \mathrm{ha}$ being statistically at par with each other, produced significantly higher seed, straw and biological yield over imazethapyr @ 20 g/ha.

The percentage increases in seed yield (54.29, 25.86 , \& 51.47), straw yield $(55.48,26.10$, \& $52.81)$ and biological yield $(55.06,26.02, \&$ 52.34 ) by pendimethalin @ $0.75 \mathrm{~kg} / \mathrm{ha}$, imazethapyr @20 g/ha and quizalofop @ $37.5 \mathrm{~g} / \mathrm{ha}$ over weedy check, respectively. Weed free gave the highest net return (99419 ₹/ha) and B:C ratio (5.04) over weedy check followed by Pendimethalin @ $0.75 \mathrm{~kg} / \mathrm{ha}$ as PE (82694₹/ha) and B:C ratio (4.97).

The crop sown on 15 to 30 October overall better than other dates of sowing it was recorded significantly higher growth and yield potential. Pendimethalin @ $0.75 \mathrm{~kg} / \mathrm{ha}$ as PE was most effective in influencing growth and development and increasing yield of chick pea.

\section{Acknowledgments}

The authors would like to thank to Department of Agronomy, College of Agriculture, Swami Keshwanand Rajasthan Agricultural University for facility support.

\section{References}

Arya, R.L. 2004. Integrated weed management in chickpea (Cicer arietinum) + mustard (Brassica juncea) intercropping system under rainfed conditions. Indian Journal of Agronomy. 49(2): 98-100.

Chaudhary, B. M., Patel, J.J. and Delvadio, D.R. 2005. Effect of weed management practices and seed rates in weeds and yield of chickpea. Indian Journal of Weed Science, 37:271-272.

GOI (2018) Agricultural Statistics at a Glance 2018, Ministry of agriculture \& Farmers Welfare Department of agriculture, cooperation \& Farmers Welfare Directorate of Economics \& Statistics New Delh : 96.

GOR (2019) Directorate of agriculture, Pant krishi Bhawan, Jaipur, Rajasthan 302005.www.dorgovraj.in

Kumar, M., Singh, R.C., Kumar, R. and Singh, S. 2003. Effect of date of sowing and row spacing on performance of chickpea genotype. Haryana Journal of Agronomy, 19(2):140-141

Kumar, S. Kumar, M. and Kadian V.S., 2006. Biomass partitioning and growth of chickpea (Cicer arietinum L.) as influenced by sowing dates and genotypes. Legume Research, 29(2): 110-113.

Mohammadnejad, Y. and Soltani, A. 2005. Shares of main stem and branches in determining grain yield of chickpea with different planting dates and densities. In proceeding of the First National Conference on Pulse in Iran 20-21 Nov. 2005.

Mukherjee, D. 2007. Techniques of weed management inchickpea-a review. Agriculture Review, 28(1): 34-41.

Prasad, D. Bhan, C. Sharma, V and Prasad, H., 2012. Effect of various plant geometry on chickpea (Cicer arietinum) under different dates of sowing: Journal of Progressive Agriculyure, 3: (2): 1216

Prasad, D. 2009. Effect of different plant population on chickpea genotypes under late sown conditions. M.Sc. Thesis, CCSHAU, Hisar.

Rajput, R. L., Shrivastava, U. K. and Yadav, R. P., 1986. Response of chickpea to sowing dates. Indian Journal 
Agronomy, 31(1): 95-96.

Ray, M., Nanda, M. K. and Khan, D. K. 2011. Effect of date of sowing and irrigation on seed yield, yield attributes and water use of Chickpea (Cicer arietinum L.) at lower Gange tic plains of West Bengal. Journal of Crop and Weed, 7(2): 30-32.

\section{How to cite this article:}

Mahaveer, M. L. Reager and Shri Rakesh. 2020. Effect of Sowing Dates and Weed Control Measure on Growth and Yield of Chickpea in Western Rajasthan. Int.J.Curr.Microbiol.App.Sci. 9(05): 2638-2645. doi: https://doi.org/10.20546/ijcmas.2020.905.302 